\title{
Nutritional properties and nutrients chemical analysis of common beans seed
}

\begin{abstract}
This paper presents a revision on the nutritional properties and chemical methods used in nutrient analysis together with their main applications in food science research. The dissertation includes a review of literature on the distribution of common beans and their nutritional and importance develops knowledge about common beans and nutrient chemical analysis. In fact, nutrients are substances required by the body to perform its basic functions. Nutrients must be obtained from diet, since the human body does not synthesize them. Nutrients are used to produce energy, detect and respond to environmental surroundings, move, excrete wastes, respire (breathe), grow, and reproduce. There are six classes of nutrients required for the body to function and maintain overall health. These are carbohydrates, lipids, proteins, water, vitamins, and minerals. Separate methods are required to describe quantity, composition, and quality of nutrient in foods. Our work has to present both nutrients compositional in common beans and analysis methods.
\end{abstract}

Keywords: nutritional properties, nutrients, chemical analysis, common beans
Volume 3 Issue 2 - 2018

\author{
Kotue TC, ${ }^{1,2}$ Marlyne Josephine M,' Wirba \\ LY,' Amalene SRH,' Nkenmeni DC,' \\ Kwuimgoin I,I Djote WNB,' Kansci G,' \\ Fokou E,' Fokam DP2 \\ 'Department of Biochemistry, University of Yaounde I, \\ Cameroon \\ ${ }^{2}$ Laboratory of Biochemistry of Physiology and Pharmacology, \\ Faculty of Medicine and Biomedical Science, Cameroon
}

Correspondence: Kotue TC, Faculty of Science, Laboratory of Food Science and Metabolism, Department of Biochemistry, University of Yaounde I, Cameroon,

Email ctkotue_bio@yahoo.fr, ckotue@uyl.uninet.cm

Received: December 21, 2017 | Published: June 08, 2018
Abbreviations: RDI, recommendation daily intake; FAME, fatty acid methyl esters; BSA, bovine serum albumin; TIU, trypsin inhibitor units; A, absorbance; TCA, trichloroacetic acid; HPLC, high-performance liquid chromatography; IUPAC, international union of pure and applied chemistry

\section{Introduction}

Nutrition is the science that interprets the interaction of nutrients and other substances in food (e.g. phytonutrients, anthocyanins, tannins, etc.) in relation to maintenance, growth, reproduction, health and disease of an organism. It includes food intake, absorption, assimilation, biosynthesis, catabolism and excretion. ${ }^{1}$ Increasing interest in nutrition, fitness and beauty consciousness has enhanced concerns over a healthy diet. Nutritional properties have assumed the status of "functional" foods, capable of providing health benefits, like prevention or delaying onset of chronic diseases, as well as meeting basic nutritional requirements. ${ }^{2}$

Nutrients are at the base of the nutrition and can be grouped into six major categories: carbohydrate, protein, lipid (fat), water, vitamins, and minerals. Carbohydrate, protein, and fat are macronutrients because they make up the bulk of your diet. Vitamins and minerals are micronutrients because they are required in much smaller amounts. However, water is a micronutrient because it does not contain energy. ${ }^{3}$ Appropriate intake of food ensures sufficient supply of nutrient. It is therefore important to analyse the composition of some foods like common beans to establish a data base necessary to know the nutritional contribution to our health.

\section{Common beans}

Common beans (Phaseolus vulgaris L.) are an important legume used for human nutrition. It is an herbaceous plant that belongs to the family of Fabaceae. Over 50 species of Phaseolus have reported from America and out of these only five namely common beans (Phaseolus vulgaris L.), year bean (Phaseolus dumosus), scarlet runner bean (Phaseolus coccineus L.), tepary bean (Phaseolus acutifolius A.) and lima bean (Phaseolus lunatus L.) are known to be domesticated. ${ }^{4}$ The plant originated from the western area of Mexico and Guatemala. It is widely cultivated and distributed from Mexico to the southern ends of the southern Andes. ${ }^{5}$ It is widely consumed throughout the world. ${ }^{6}$ Common beans are one of the staple foods in Africa, India, and Latin America. Because of their nutritional composition, these economical foods have the potential to improve the diet quality and long-term health of those who consume beans regularly. ${ }^{7}$

Common beans are often a main source of protein, dietary fiber and minerals in diet, occupying a very important worldwide place in human alimentation, offering benefits for human health. The bean carbohydrates are composed primarily of starch, following by dietary fiber and $\alpha$-galactosyl derivatives of sucrose. The major proteins of bean are globulins $(54-79 \%)$ and albumins (12-30\%) and the presence of protease inhibitors ( $\alpha$-amylase, chymotrypsin and trypsin), lectins and lipoxygenase were been verified. ${ }^{8}$ But the presence of phytate, tannins and oxalate referred to anti-nutritive factors that affect the nutritional quality by interacting with intestinal tract and also reduce protein digestibility and amino acid absorption. ${ }^{9}$ According to ${ }^{10}$ unless these substances are destroyed by heat or other treatments, they can exert adverse physiological effects when utilized by animals and man.

Because of their high concentration of health-promoting nutrients, consuming more beans in diet could improve overall health and also decrease the risk of developing certain diseases, including heart disease, obesity and many types of cancers. The 2010 Dietary Guidelines for Americans recommend consuming 1.5 cups of beans per week to take advantage of this potential health benefits. ${ }^{11}$ 
Dry beans are very good source of low fat protein. They contain between 21 to $25 \%$ protein by weight, which is much higher than other vegetable products. In many parts of the world, they provide a substantial proportion of the total protein intake for the population. The intake of dried beans as a protein source is extremely important worldwide as they provide a good source of protein at minimal cost relative to the production of animal protein sources.

Beans are one of the most of nutritionally complete foods available. In fact, no other food comes close to beans in providing protein, iron, magnesium, zinc, potassium and fibers together in high amounts. Following are some of reasons why beans are a key ingredient in a healthy diet of all ages: high in complex carbohydrate, in protein, in dietary fiber, in folate; low in fat, in sodium, cholesterol free; rich in vitamins and minerals.

The new food pyramid now uses the term ounce-equivalents in place of the traditional ounce serving size for the meat and beans group. A $1 / 4$ cup serving of cooked dry beans equals an ounceequivalent. In the vegetable group, the serving is based directly on a measured amount of beans. For example, $1 / 2$ cup of cooked beans equal $1 / 2$ cup of vegetables. ${ }^{12}$

The United States Department of Agriculture ${ }^{13}$ has an extensive nutritional profile for edible beans (Table 1) in the National Nutrient Database for Standard Reference.

Table I Nutrient profile of beans. ${ }^{13}$

\begin{tabular}{|c|c|c|c|c|c|c|c|c|c|}
\hline $\begin{array}{l}1 / 2 \text { cup }(85-89 \mathrm{~g}) \\
\text { cooked beans }\end{array}$ & Black & Cranberry & $\begin{array}{l}\text { Great } \\
\text { northern }\end{array}$ & $\begin{array}{l}\text { Dark red } \\
\text { kidney }\end{array}$ & $\begin{array}{l}\text { Light red } \\
\text { kidney }\end{array}$ & Navy & pink & pinto & $\begin{array}{l}\text { Small } \\
\text { red }\end{array}$ \\
\hline \%calories & 114 & 120 & 104 & 109 & 110 & 127 & 126 & 123 & 112 \\
\hline \%calories from fat & 4 & 3 & 3 & 1 & 1 & 4 & 3 & 4 & I \\
\hline Fat(g) & 0.5 & 0.4 & 0.4 & 0.2 & 0.1 & 0.6 & 0.4 & 0.5 & 0.2 \\
\hline $\operatorname{Protein}(\mathrm{g})$ & 8 & 8 & 7 & 8 & 8 & 8 & 8 & 8 & 8 \\
\hline Carbohydrates(g) & 21 & 22 & 19 & 19 & 20 & 24 & 24 & 22 & 20 \\
\hline Dietary fiber(g) & 8 & 9 & 6 & 8 & 8 & 9 & 5 & 8 & 6 \\
\hline Calcium(mg) & 23 & 43 & 60 & 39 & 58 & 63 & 44 & 40 & 25 \\
\hline Magnesium(mg) & 60 & 44 & 44 & 40 & 40 & 48 & 56 & 43 & 40 \\
\hline Iron(mg) & 2 & 2 & 2 & 2 & 3 & 2 & 2 & 2 & 3 \\
\hline Potassium(mg) & 306 & 342 & 346 & 335 & 371 & 354 & 329 & 373 & 357 \\
\hline Sodium(mg) & 1 & I & 2 & 4 & 4 & 0 & 2 & I & 2 \\
\hline Riboflavin (mg) & 0.05 & 0.06 & 0.05 & 0.05 & 0.05 & 0.06 & 0.04 & 0.05 & 0.05 \\
\hline Vitamine $\mathrm{K}(\mu \mathrm{g})$ & 0 & 0 & 0 & 7 & 6 & 0.5 & 3 & 3 & 3 \\
\hline Folate & 128 & 183 & 90 & 65 & 65 & 127 & 142 & 147 & 115 \\
\hline
\end{tabular}

\section{Carbohydrate}

Carbohydrate is considered an energy (calorie) yielding nutrient. However, not all carbohydrate provides energy. Both simple and complex forms of carbohydrates exist in beans. The simple form includes sugars such as glucose. In contrast, complex forms of carbohydrates such as starches and dietary fiber are not always a source of energy. Starches can be digested to produce glucose; which is the used as an energy source. Fiber does not digest and therefore cannot produce any energy. ${ }^{14}$ Thus consumption of beans provides multiple form of carbohydrate. Dietary fiber is composed of both soluble and insoluble forms. Beans vary in the composition of soluble to insoluble fibers. As general rule, the fiber in beans is composed of between $60-85 \%$ insoluble and $40-55 \%$ soluble. A $60: 40$ ratio is most common in cooked beans. Approximately $75-80 \%$ of the fiber is found in the beans hull. ${ }^{15}$

\section{Proteins content}

Proteins content in kidney (29.45\%), pinto (26.8\%), black $(25.31 \%)$ and navy $(24.48 \%)$ beans are just a few examples of the valuable protein source bean provide. Consuming beans are a great way to get a low fat source of protein. ${ }^{13}$ We must consume proteins as a source of amino acid which the body in turn uses makes proteins necessary for life. There are approximately nine essential amino acids. The three most important essential amino acids in beans include lysine, cysteine and methionine. ${ }^{16}$

\section{Vitamins and minerals}

Beans are excellent sources of iron, magnesium, zinc potassium and folic acid. ${ }^{13}$ The recommendation daily intake (RDI) for iron falls between 8 and $11 \mathrm{mg}$ for men and women, respectively. A $1 / 2$ cup serving of beans provides approximately 11\% RDI for iron. A $1 / 2$ cup serving of beans provide 10 to $15 \%$ of the 320 to $42 \mathrm{mg}$ RDI for magnesium. Beans provide approximately 300 to $43 \mathrm{mg}$ of potassium per $1 / 2$ cup serving or $6-10 \%$ of the RDI for potassium. Approximately, beans provide $0.75-0.95 \mathrm{mg}$ of zinc per $1 / 2$ cup serving or approximately $10-11 \%$ of the RDI for women and $6-8 \%$ of RDI for men. The RDI for folic acid (or folate) is $400 \mu \mathrm{g}$ per day. A $1 / 2$ cup serving of cooked beans provide $65-183 \mu$ g or $16-46 \%$ of RDI. Beans also provide $8-15 \%$ of the RDI for copper $8 \%$ of the RDI for selenium, and $2-6 \%$ of the RDI for calcium. Beans also provide $19-26 \%$ of the adequate intake value for manganese. 
Nutritional properties of food depending upon its composition and physical properties. Separate methods are required to describe quantity, composition, and quality of nutrients in foods. Our work has to present also nutrient compositional in common beans and analysis method.

\section{Nutrient composition}

This exhaustive check-list has presented parameters of beans. ${ }^{17}$

\section{Proximate component}

The term proximate component refers to those macronutrients that include water (moisture), crude protein, crude lipid (fat), carbohydrate, crude fiber and $a \mathrm{ash}^{18}$. The other parameters are:

i. Soluble and insoluble fiber

ii. Amino acids: Essential and non-essential amino acids.

iii. Fatty acids and Phytostérols

iv. Mineral composition and trace elements: It is about: $\mathrm{Na} ; \mathrm{K} ; \mathrm{Ca} ; \mathrm{P}$; $\mathrm{Mg} ; \mathrm{Fe} ; \mathrm{Mn} ; \mathrm{Cu} ; \mathrm{Zn} ; \mathrm{S}$; I and $\mathrm{Se} ; \mathrm{Cl} ; \mathrm{Pb} ; \mathrm{Co} ; \mathrm{Cr} ; \mathrm{Cd} ; \mathrm{Hg}$.

\section{Vitamins}

\section{a. Fat soluble vitamins}

Vitamin A (retinol); vitamin D3 (chlolecalciferol); vitamin D2 (ergocalciferol); vitamin E ( $\alpha$-tocopherol); vitamin K (phylloquinone); ß-carotene.

\section{b. Water soluble vitamins}

Vitamins B1 (thiamin); vitamin B2 (riboflavin), vitamin B6 (pyridoxine); niacin; pantothenic acid; folic acid; biotin; vitamin B12 (cobalamin); vitamine $\mathrm{C}$.

\section{Anti-nutrients factors}

Tannins; phytate, proteases inhibitors; lectins or hemagglutinins.

\section{Analytical methods}

Reference method must be used. The choice of the analytical method is crucial for the validation and the signification of the result.

\section{Proximate component analysis}

The dry beans must used in the study and must finely ground into flour and kept at $4-6^{\circ} \mathrm{C}$ in sealed polyethylene bags until analysis.

Moisture, ash, crude fat, crude protein, and carbohydrate will be analyse according to $\mathrm{AOAC}^{19}$ methods as described below. Samples were analyzed in triplicate.

\section{Determination of moisture}

Water content is determined by removing moisture and then by measuring weight loss;

$3 \mathrm{~g}$ of bean powder is accurately weighed in a pre-weighed petridish and dried in a hot air oven for $6-12 \mathrm{~h}$ at $100 \pm 2^{\circ} \mathrm{C}$. The dish with sample is cooled in desiccators and weighed. This exercise is repeated until the difference in weight between two successive weighing becomes constant. From the weight loss during drying, amount of moisture is calculated using the following formula and the moisture can be represented in percentage.

$$
\text { Moisture }(\%)=\frac{\left(W_{1}-W_{2}\right)}{W} \times 100
$$

$\mathrm{W}_{1}=$ Weight of sample with petridish before drying

$\mathrm{W}_{2}=$ Weight of sample with petridish after drying

$\mathrm{W}=$ Weight of sample

\section{Determination of ash content}

$1 \mathrm{~g}$ of dried sample is accurately weighed into pre-weighed, clean crucible. The crucible is heated to the point of charring of the sample on a hot plate. The crucible with the carbon residue obtained as a result of ignition, is placed in muffle furnace at temperature of $650^{\circ} \mathrm{C}$ until the carbon residue disappears. The sample is allowed to cool and then weighed. From the difference in weight obtained the ash content is calculated using the formula:

Total ash content $(\%)=\frac{\text { Weight of crucible with ash }(\mathrm{g})}{\text { Weight of cruicble with sample }(\mathrm{g})} \times 100$

\section{Crude fat estimation}

Take $10 \mathrm{~g}$ of sample in a thimble and plug the top of the thimble with a wad of fat-free cotton. Drop the thimble into the fat extraction tube of a Soxhlet apparatus. Attach the bottom the extraction tube to a Soxhlet flask. Pour approximately $75 \mathrm{~mL}$ or more of hexane through the sample in the tube into the flask. Attach the top of fat extraction tube to the condenser. Extract the sample for $6 \mathrm{~h}$ or longer on a heating mantle at $40^{\circ} \mathrm{C}$. At the end of the extraction period, remove the thimble from the apparatus and concentrate the extract at rotavapor at $40^{\circ} \mathrm{C}$. Dry at $100^{\circ} \mathrm{C}$ for $1 \mathrm{~h}$, cool and weigh. The difference in weights gives the ether soluble material present in the sample.

$$
\text { Crude Fat }(\%)=\frac{\text { Weight of hexane soluble material }}{\text { Weight of sample }} \times 100
$$

\section{Determination of crude proteins}

The conventional test for protein measurement is based on the nitrogen content (Kjeldahl method). $0.5 \mathrm{~g}$ of sample and digestion mixture (copper sulphate + potassium sulphate) is weighed into a Kjeldahl flask and $10 \mathrm{~mL}$ of concentrated $\mathrm{H}_{2} \mathrm{SO}_{4}$ is added. The Kjeldahl flask will be then heated on a mantle (in slanting position) until colour of solution changes to pale blue green. This clear solution will made up to $25 \mathrm{~mL}$ under cold conditions. The Kjeldahl apparatus is set up for protein estimation. $20 \mathrm{~mL}$ of $4 \%$ boric acid and $1 \mathrm{~mL}$ of mixed indicator (bromocresol green) is taken in conical flask and placed under condenser. $5 \mathrm{~mL}$ of sample with $20 \mathrm{~mL}$ of $40 \% \mathrm{NaOH}$ and $10 \mathrm{~mL}$ water are added to distillation tube through funnel. When water starts boiling inside the round bottom flask, steam produced then passes into distillation tube. $\mathrm{NH}_{3}$ evolved in distillation tube is trapped in boric acid. Upon ammonia evolution, the colour of boric acid changes to blue. For maximum ammonia evolution, the process is continued for $20 \mathrm{~min}$. The solution is then titrated with standard $\mathrm{HCl}(0.01 \mathrm{~N})$ until blue colour of the solution disappears.

Amount of nitrogen in the samples is calculated by the following equation 


$$
\begin{gathered}
\% \text { of Nitrogen }=\frac{14 \times \text { Normality of } \mathrm{HCl} \times \Delta V \times 100}{\text { Weight of Sample } \times 1000} \\
\% \text { Protein }=\% \text { of Nitrogen } \times 6.24
\end{gathered}
$$

\section{Determination of Carbohydrate}

Carbohydrate is found by difference method and expressed as percentage of carbohydrate.

$$
\begin{aligned}
& \text { Carbohydrate }(\%)=100-[\text { Moisture }+ \text { Ash }+ \text { Fat }+ \text { Protein }] \\
& \text { Determination of fiber } \\
& \text { Determination of Crude fiber }
\end{aligned}
$$

Crude fiber is determined as described by. ${ }^{19}$

Around $1 \mathrm{~g}$ of sample is taken into the beaker. Added $60 \mathrm{ml}$ of boiling sulfuric acid, and connect it with the digestion apparatus. Boil for exactly 30 minutes, filter through filtering cloth and wash with hot water until it is free from acid. Transfer the residue on the cloth into the flask with $200 \mathrm{ml}$ of boiling sodium hydroxide solution. Immediately connect the flask with the digestion apparatus and boil further for exactly 30 minutes. Remove the flask and immediately filter through Gooch crucible or alundum crucible. Wash with hot water until it is free from alkali and then with $10 \mathrm{ml}$ of alcohol. Dry at $105-110^{\circ} \mathrm{C}$ in an air oven for about 2 hours. Cool to room temperature in desiccator and weigh. Repeat the process of 30minute drying, cooling and weighing until the difference between two successive weightings is less than $1 \mathrm{mg}$. Note the lowest weight which shall be considered as the weight of crucible and contents after drying.

Incinerate the contents and the crucible in the electric muffle furnace at $620^{\circ} \mathrm{C}$ for about 30 minutes. Cool to room temperature in desiccator and weigh.

Repeat the process of 30 minute incinerating, cooling and weighing until the difference between two successive weighings in less than $1 \mathrm{mg}$. Note the lowest weight which shall be considered as the weight of crucible and ash after incinerating. The difference between the two weightings is the weight of crude fiber.

$$
\text { Crude fibre, \% by weight }=\frac{\left(W_{1}-W_{2}\right)}{W} \times 100
$$

\section{Where, $\mathrm{W}$ is weight of sample, $\mathrm{g}$}

$\mathrm{W}_{1}$ is weight of crucible and contents after drying, $\mathrm{g}$

$\mathrm{W}_{2}$ is weight of crucible and ash after incinerating, $\mathrm{g}$

\section{Insoluble and soluble dietary fibers}

Insoluble dietary fiber content must be determined by enzymicgravimetric methods and soluble dietary fiber content was calculated by difference using crude fiber result. ${ }^{20}$ The enzymes employed for dietary fiber are: $\alpha$-amylase (Termamyl 120L), protease (Flavourzyme), and amyloglucosidase (AMG 300L).

The fiber was extracted enzymatically from fat-extracted samples, using Soxlet's method. Dry sample was homogenized with $40 \mathrm{ml}$
MES/TRIS ( $\mathrm{pH} 8.2$ ) solution and $\alpha$-amylase solution was added. Then heating with $95^{\circ} \mathrm{C}$ water bath was carried out. After which, the reactants was cooled at room temperature and washed with distilled water, adding protease solution in $60^{\circ} \mathrm{C}$ water bath. It is mixed with $5 \mathrm{ml}$ of $0.56 \mathrm{~N} \mathrm{HCl}$ solutions, adjusted at $\mathrm{pH} 4.0$. After then, $300 \mathrm{ul}$ of amyloglucosidase solution is added and stirred at $60^{\circ} \mathrm{C}$ hot plate. To extract the insoluble fiber, the solution is filtered using glass filter, with $1 \mathrm{~g}$ celite, and the filtrate is washed with $78 \%$ ethanol, $95 \%$ ethanol and acetone in turn. After overnight, the residue in the glass filter is weighed for the insoluble fiber. The filtrate collected is added $95 \%$ ethanol and distilled water. For extract of soluble fiber, the solution is filtered using a glass filter with celite and the filtrate is washed with $15 \mathrm{ml}$ of $78 \%$ ethanol, $95 \%$ ethanol and acetone, in turn. After overnight, the residue in the glass filter is weighed for the insoluble fiber.

\section{Amino acids}

Amino acids are determined using a HPLC using appropriate column according to the method. ${ }^{21}$

$50 \mathrm{~g}$ of powder in hexane $(100 \mathrm{~mL})$ is delipided using soxhlet dispositive. The free amino acids content in delipidate powdered material is extracted in distiller water $(100 \mathrm{~mL})$ using soxhlet dispositive during 8hours. The free amino acids content in distiller water are ready for HPLC analysis. The total protein is extracted from delipidate powder used to extract free amino acids with $1250 \mu \mathrm{L}$ of $2 \%$ SDS in $0,05 \mathrm{M}$ sodium phosphate buffer PH 6.9. The extracts will be centrifuged at $10500 \mathrm{rpm}$ for $10 \mathrm{~min}$. Fifty microlitres of the supernatant is hydrolyzed using $100 \mu \mathrm{L} 6 \mathrm{~N} \mathrm{HCl}$ in an oven at $110^{\circ} \mathrm{C}$ for $24 \mathrm{~h}$. After hydrolysis, $50 \mu \mathrm{L}$ of $\mathrm{CaCO}_{3}$ is added to neutralize the reaction. The whole is then centrifuged at $10.500 \mathrm{rpm}$ for $10 \mathrm{~min}$ and $10 \mu \mathrm{L}$ of supernatant can be use for HPCL analysis. A standard solution containing $1.25 \mu \mathrm{mol} / \mathrm{mL}$ of each amino acid in $0.1 \mathrm{~N}$ hydrochloric acid will created.

Chromatography is carried out at a constant temperature of $30^{\circ} \mathrm{C}$ using a gradient elution as follows. Eluant $\mathrm{A}$ is an aqueous buffer prepared by adding $0.5 \mathrm{~mL} / \mathrm{L}$ TEA to $0.14 \mathrm{M}$ sodium acetate and titrating it to $\mathrm{pH} 6.20$ with glacial acetic acid; eluant $\mathrm{B}$ is acetonitrilewater $(60: 40[\mathrm{v} / \mathrm{v}])$.

The detection limit of each amino acid is calculated in accordance with American Chemical Society guidelines.

\section{Fatty acids and phytostérols \\ Fatty acids}

The oil extracted from powdered whole seeds in a Soxhlet extractor with hexane is analysed by the standard AOAC methods. ${ }^{19}$ Crude oil is analyzed as methyl esters to determine the fat acids composition. Fatty acid methyl esters (FAME) were obtained through a two steps method with sodium methoxyde and $\mathrm{HCl}$ as catalysts, and then analyzed by capillary column gas chromatography using appropriate column. The identification of the peaks is made by comparison of retention times of methyl esters obtained and analyzed in the same conditions of known oils as olive, and sunflower.

\section{Phytostérols}

The unsaponifiable and sterolic fractions are obtained using standard IUPAC method. ${ }^{22}$ After isolation from the thin layer 
chromatography plate, the sterol fraction prepared according to the standard EN ISO6799, and is further analyzed by gas chromatography with a FISON GC 8000 unit equipped with a FID detector. Sterols are quantified by internal standard method using cholesterol. They are identified by comparison to the data obtained by running authentic sterol standard.

\section{Mineral composition and trace elements}

The main minerals found in bean are $\mathrm{Na}$; $\mathrm{K}$; $\mathrm{Ca}$; $\mathrm{Mg}$; $\mathrm{Fe}$; $\mathrm{Mn}$ and $\mathrm{Zn}^{23}$

Mineral contents of powder sample are determined by atomic absorption spectrometry/flame photometry according to the methods. ${ }^{24}$

For wet digestion of sample, $1 \mathrm{~g}$ of the powdered sample is taken in digesting glass tube. $12 \mathrm{ml}$ of $\mathrm{HNO}_{3}$ is added to the food samples and mixture is kept for overnight at room temperature. Then $4 \mathrm{ml}$ perchloric acid $(\mathrm{HClO})$ is added to this mixture and is kept in for the fumes block for digestion. The temperature was increased gradually, starting from $50^{\circ} \mathrm{C}$ and increasing up to $250-300^{\circ} \mathrm{C}$. The digestion completed in about $70-85 \mathrm{~min}$ as indicated by the appearance of white fumes. The mixture is left to cool down and the contents of the tubes are transferred to $100 \mathrm{ml}$ volumetric flasks and the volumes of the contents are made to $100 \mathrm{ml}$ with distilled water. The wet digested solution is transferred to plastic bottles labeled accurately. Put the sample in many tube to centrifuge it at $3000 \mathrm{rpm}$ to $10 \mathrm{~min}$. Use supernatants for mineral determination.

Determination of Iron (Fe), Zinc (Zn), Calcium (Ca), Manganese (Mn) and Magnesium (Mg) by Atomic Absorption Spectrometry

The digested sample was analyzed for mineral contents by Atomic Absorption Spectrophotometer. Different electrode lamps were used for each mineral. The equipment is run for standard solutions of each mineral before and during determination to check that it is working properly.

The dilution factor for all minerals except $\mathrm{Mg}$ is 100. For determination of $\mathrm{Mg}$, further dilution of the original solution was done by using $0.5 \mathrm{ml}$ original solution and enough distilled water is added to it to make the volume up to $100 \mathrm{ml}$. Also for the determination of $\mathrm{Ca}, 1.0 \mathrm{ml}$ lithium oxide solution is added to the original solution to unmask $\mathrm{Ca}$ from $\mathrm{Mg}$. The concentrations of minerals recorded in terms of "ppm" are converted to milligrams ( $\mathrm{mg}$ ) of the minerals by multiplying the ppm with dilution factor and dividing by 1000 , as follows:

$$
M W=\frac{\text { absorbency } x \text { dry } w t . x D}{\text { Wt.of samplex } 1000}(\mathrm{mg} / \mathrm{g})
$$

\section{Determination of Sodium ( $\mathrm{Na}$ ) and Potassium (K) by flame photometer}

$\mathrm{Na}$ and $\mathrm{K}$ analysis of the sample are done by the method of flame photometry. The same wet digested food sample solutions as used in Atomic Absorption Spectrometry are used for the determination of $\mathrm{Na}$ and K. Standard solutions of 20, 40, 60, 80 and 100 milliequivalent/L are used both for $\mathrm{Na}$ and $\mathrm{K}$. The calculations for the total mineral intake involve the same procedure as given in Atomic Absorption Spectrometry.

\section{Vitamins}

\section{Fat soluble vitamins}

\section{*vitamin E ( $\alpha$-tocopherol)}

It is particularly about vitamin $\mathrm{E}$ ( $\alpha$-tocopherol) and $\beta$-carotene.

Tocopherol in the oil sample is determined by HPLC using appropriate column. $10 \mathrm{mg}$ of the crude oil is dissolved in $10 \mathrm{ml}$ of hexane. An aliquot of this solution is injected on to column the mobile phase is hexane/isopropanol $(99 / 1 \mathrm{v} / \mathrm{v})$ at a flow rate of $1 \mathrm{ml} / \mathrm{min}$. The tocopherol is identified by comparison of retention times with authentic standard.

\section{*B-carotene}

The value of $\beta$-carotene concentration is obtained by HPLC analysis. ${ }^{25}$ In order to avoid possible degradation; the $\beta$-carotene is extracted directly in oil sample with solvent without saponification. Aliquots $(2 \mathrm{~g})$ of oil were extracted $5 \mathrm{~min}$ with acetone: hexane (4:6). After the extraction, the solvent is evaporated to dryness under a stream of nitrogen and the residue is reconstituted with $1 \mathrm{ml}$ of eluent solution and is colled in a screw-cap vial for HPLC analysis. Determination of $\beta$-carotene, consisted in the treatment of sample extraction with $1000 \mu 1$ aqueous potassium hydroxide solution $(60 \%$ $\mathrm{w} / \mathrm{v}$ ) for $15 \mathrm{~min}$ in a $45^{\circ} \mathrm{C}$ water bath. Following saponification, each sample is extracted with $1000 \mu 1$ hexane. The sample is vortexed for $3 \mathrm{~min}$, centrifuged at $1500 \times \mathrm{g}$ for $5 \mathrm{~min}$, and the organic hexane layer is decanted into an evaporating tube. This procedure is repeated and the second hexane extract is combined with that from the first. The hexane is then evaporated to dryness with a stream of nitrogen gas. The remaining residue is reconstituted with $1 \mathrm{ml}$ of eluent solution. Aliquots of $20 \mu 1$ are used for HPLC analysis using appropriate column.

\section{Water soluble vitamins}

Common beans are an excellent source of the water-soluble vitamins thiamin, riboflavin, niacin and folate (also known as folacin and folic acid). But the main water soluble vitamin in bean is folic acid. ${ }^{13}$ Analytical technique used for determination of folate content is HPLC-method. ${ }^{26}$

Standard stock solution of folic acid is prepared by dissolving $25.0 \mathrm{mg}$ of folic acid in $50.0 \mathrm{ml}$ of water. $1 \mathrm{ml}$ of the standard stock solution of folic acid is diluted to $50 \mathrm{ml}$ with $15 \%$ methanol solution.

Twenty mg of sample powder are weighed and transferred into a $50 \mathrm{ml}$ volumetric flask and $15 \%$ of methanol solution is added. The mixture is sonicated (15min) and diluted to the mark with the same solvent. $1 \mathrm{ml}$ of this solution is transferred into a $10 \mathrm{ml}$ volumetric flask, diluted to the mark with the same solvent and filtered through a $0.2 \mu \mathrm{m}$ Millipore filter.

Prior to injection into the chromatographic system, all analytical solutions are degassed by sonication. All the prepared sample solutions are first chromatographed to ensure that interfering peaks are not present. $10 \mu \mathrm{l}$ and $100 \mu \mathrm{l}$ aliquots of the standard solutions and sample solutions are injected.

\section{Anti-nutrients factors}

Tannins; phytate, proteases inhibitors; lectins or hemagglutinins. 


\section{Tannins}

Total tannins are determined colorimetrically as described. ${ }^{19}$

In flask of $100 \mathrm{ml}$, one introduces: $5 \mathrm{ml}$ of distilled water; $1 \mathrm{ml}$ of acetone powder extract; $5 \mathrm{ml}$ of reagent of Folin Ciocalteu; $10 \mathrm{ml}$ of the solution saturated with $\mathrm{CO}_{3} \mathrm{Na}_{2}$ (this saturated solution will prepared starting from $43,75 \mathrm{~g}$ of sodium carbonate dissolved in $100 \mathrm{ml}$ of hot water $\left(70\right.$ with $\left.80^{\circ} \mathrm{C}\right)$ after cooling the solution is filtered then adjusted to $125 \mathrm{ml}$ ). After mechanical agitation, the preparation rests during 30minutes. The measurement of the optical density is made to $760 \mathrm{~nm}$. A range standard of tannic acid is prepared under the same conditions of which concentrations going from 0 to $0.1 \mathrm{~g} / \mathrm{l}$. Quantity of tannins are calculated using the equation of the calibration curve.

\section{Phytic acid}

Phytic acid is determined according to the method. ${ }^{27}$

Phytic acid is extracted from $3 \mathrm{~g}$ powder sample with $50 \mathrm{ml}$ of $3 \%$ TCA by shaking at room temperature followed by high speed centrifugation. The phytic acid in supernatant is precipitated as ferric phytate by adding excess ferric chloride and centrifuged. The ferric phytate is converted to ferric hydroxide with a few $\mathrm{ml}$ of water and $3 \mathrm{ml}$ of $1.5 \mathrm{~N} \mathrm{NaOH}$, and then the iron content present in the sample is estimated. The phytate phosphorus is calculated from the iron results assuming a 4:6 iron: phosphorus molecular ratio. The phytic acid is estimated by multiplying the of phytate phosphorus by the factor 3.55 based on the empirical formula $\mathrm{C}_{6} \mathrm{P}_{6} \mathrm{O}_{24} \mathrm{H}_{18}$.

\section{Proteases inhibitor: trypsin inhibitor activity case}

Trypsin inhibitor activity was determined according to the method $^{28}$ using benzoyl-DL-arginine-P-nitroanalide hydrochloride as the substrate.

A $4 \mathrm{~g}$ of defatted sample is treated with $40 \mathrm{ml}$ of $0.05 \mathrm{M}$ sodium phosphate buffer, $\mathrm{pH} 7.5$ and $40 \mathrm{ml}$ of distilled water. The sample is shaken for $3 \mathrm{~h}$ and centrifuged at $700 \mathrm{~g}$ for $30 \mathrm{~min}$ at $15^{\circ} \mathrm{C}$. Supernatant is diluted in order to obtain inhibition between 40 and $60 \%$ of enzyme activity. Incubation mixture consisted of $0.5 \mathrm{ml}$ trypsin solution $(5 \mathrm{mg} /$ $\mathrm{ml}), 2 \mathrm{ml} \mathrm{2 \%}(\mathrm{w} / \mathrm{v})$ Bapna, $1.0 \mathrm{ml}$ sodium phosphate buffer $(\mathrm{pH}$ $7.5,0.1 \mathrm{M}), 0.4 \mathrm{ml} \mathrm{HCl}(0.001 \mathrm{M})$ and sample extract $(0.1 \mathrm{ml})$. Total volume of incubation mixture was maintained at $4.0 \mathrm{ml}$. Incubation is carried out in a water bath at $37^{\circ} \mathrm{C}$ for $20 \mathrm{~min}$ after which $6.0 \mathrm{ml}$ of $5 \%$ TCA (trichloroacetic acid) solution is added to stop the reaction. Blank sample is treated similarly through the entire determination. Absorbance (A) is read at $410 \mathrm{~nm}$ wavelength in a spectrophotometer. Results are expressed as trypsin inhibitor units (TIU). One TIU is defined as an increase of 0.01 in absorbance units under conditions of assay. Trypsin inhibitory activity is defined as the number of TIU.

\section{Hemagglutinin}

Hemagglutinin activity is estimated according to the method. ${ }^{29}$

The powder $(5 \mathrm{~g})$ is mixed with $0.15 \mathrm{M} \mathrm{NaCl}(1: 8, \mathrm{w} / \mathrm{v})$ for $48 \mathrm{~h}$ at $4^{\circ} \mathrm{C}$, and filtered through 80 -mesh grid. Subsequently, the filtrate is centrifuged at $9168 \mathrm{~g}$ for 30 minutes, and the supernatant is fractionally precipitated with ammonium sulfate at $10 \%-100 \%$ saturation, respectively. The four pellets are combined, dissolved in a minimal volume of water, and dialyzed against distilled water at $4{ }^{\circ} \mathrm{C}$. Bradford's method is used for protein quantification, using bovine serum albumin (BSA) as the standard.

\section{Conclusion}

As shown in this study, nutritional properties and nutrients chemical analysis of common beans seed (Phaseolus vulgaris L.). Common beans are often a main source of protein, dietary fiber and minerals in diet, occupying a very important worldwide place in human alimentation, offering benefits for human health. Therefore, separate methods are required for estimating nutrients composition.

\section{Acknowledgments}

None.

\section{Conflict of interest}

Author declares no conflict of interest.

\section{References}

1. Rosalinda T Lagua, Virginia S Claudio. Nutrition and Diet Therapy Reference Dictionary. New York: Chapman \& Hall; 1995. 69 p.

2. Willett WC. Diet and health: what should we eat? Science. 1994;264(5158):532-537.

3. Lennernas M, Fjellstrom C, Becker W, et al. Influences on food choice perceived to be important by nationally representative samples of adults in the European Union. Eur J Clin Nutr. 1997;51:S8-S15.

4. Debouck DG. Systematics and morphology. Common beans; research for crop improvement. Wallingford, UK: CAB Publishing; 1991. p. 55-118.

5. Voysest OL, Fernandez FC. Bean Improvement by introduction and selection. International Center for Tropical Agriculture, Colombia; 1986. $32 \mathrm{p}$.

6. Juhi M, Rattan DS, Vikas SJ, et al. Assessment of phenolic components and antioxidative activities of Phaseolus vulgaris L. International Journal of Integrative Biology. 2010;9(1):26-30.

7. Mitchell DC, Lawrence FR, Hartman TJ, et al. Consumption of dry beans, peas, and lentils could improve diet quality in the US population. $J \mathrm{Am}$ Diet Assoc. 2009;109(5):909-913.

8. Pujolà M, Farreras A, Casañas F. Protein and Starch Content of Raw, Soaked and cooked beans (Phaseolus vulgaris L.). Food Chemistry. 2007;102(4):1034-1041.

9. Nowacki E. Heat-stable and anti-nutritional factors in leguminous plants. Advances in Legume Science. UK: Royal Botanic Gardens, Kew, Richmond, Survey; 1980. p. 171-177.

10. Liener IE. Implications of anti-nutritional components in soybean foods. Crit Rev Food Sci Nutr. 1994;34(1):31-67.

11. United States Department of Agriculture: Health and Human Services. Dietary Guidelines for Americans. 7th ed. Washington, DC: U.S. Government Printing Office; 2010. 154 p.

12. United States Department of Agriculture: Center for Nutrition Policy and Promotion. Food Guide Pyramid: A Guide to Daily Food Choices. Avenue Building 005, Room 107, BARC-West Beltsville, Maryland; 2005. 16 p.

13. United States Department of Agriculture: Branded Food Products Database. Composition of Foods Legumes and legume products; raw, processed, prepared. Agriculture Handbook; 2016. p. 8-16.

14. Akerberg AK, Liljeberg HG, Granfeldt YE, et al. An in vitro method, based on chewing, to predict resistant starch content in foods allows parallel determination of potentially available starch and dietary fiber. $J$ Nutr. 1998;128(3):651-660. 
15. Landa-Habana L. Effect of cooking procedures and storage on starch bioavailability in common beans (Phaseolus vulgaris L.). Plant Foods Hum Nutr. 2004;59(4):133-136.

16. Lindorff K, Rogen P, Poci E, et al. Protein folding and the Organization of the Protein Topology Universe. Trends Biochem Sci. 2005;30(1):13-19.

17. Sotelo A, Sousa H, Sánchez M. Comparative study of the chemical composition of wild and cultivated beans (Phaseolus vulgaris L.). Plant Foods for Human Nutrition. 1995;47(2):93-100.

18. United States Department of Agriculture: National Nutrient Database for Standard Reference, Release 26. Composition of Foods Raw, Processed, Prepared. Beltsville, Maryland 20705; 2013. 136 p.

19. AOAC. Official methods of analysis. 15th ed. Washington, DC, USA; 1990. $12 \mathrm{p}$

20. AOAC. Official methods of analysis of the AOAC. Total, soluble and insoluble dietary fiber in foods. Enzymatic-gravimetric method, MESTRIS buffer. $16^{\text {th }}$ ed. Arlington; 1995. 4 p.

21. Gonzalez Castro MJ, Lopez Hernández J, Simal Lozano J, et al Determination of Amino Acids in Green Beans by Derivatization with Phenylisothiocianate and High-Performance Liquid Chromatography with Ultraviolet Detection. Journal of Chromatographic Science. 1997;35(4):181-185.
22. IUPAC. Oils and fats. Standard Methods for the Analysis of Oilseeds, Fats and Derivatives. 7th ed. International Union of Pure and Applied Chemistry, Blackwell Scientific Publications, Oxford; 1987.

23. Tako E, Glahn RP, Laparra JM, et al. Iron and Zinc: Bioavailabilities to Pigs from Red and White Beans (Phaseolus vulgaris L.) are Similar. $J$ Agric Food Chem. 2009;57(8):3134-3140.

24. AOAC. Official methods of analysis of the association of official's analytical chemists. 17th ed. Association of official analytical chemists, Arlington, Virginia; 2003.

25. Furtado J, Siles X, Campos H. Carotenoid concentrations in vegetables and fruits common to the Costa Rican diet. Int $J$ Food Sci Nutr. 2004;55(2):101-113.

26. AOAC. Total Folates in Cerals and Cereal foods. In: 10th ed. Gaithersburg; 2004.

27. Wheeler EI, Ferrel RE. A method for phytic acid determination in wheat and wheat fractions. Cereal Chemistry. 1971;48:312-316.

28. Kakade ML, Simons N, Liener IE. An evaluation of natural vs synthetic substrates for measuring the antitryptic activity of soy bean samples. Cereal Chemistry. 1969;46:518-528.

29. Liener IE, Hill EG. The effect of heat treatment on the nutritive value and hemagglutinating activity of soy bean oil. J Nutr. 1953;49(4):609-620. 